\title{
PERKEMBANGAN PEMANFAATAN LAHAN DI KAWASAN SEKITAR BANDAR UDARA AHMAD YANI SEMARANG
}

\author{
Iskandar Sillia ${ }^{1}$, Nany Yuliastuti ${ }^{2}$ \\ 1Program Studi Magister Perencanaan Wilayah dan Kota, Universitas Diponegoro \\ Jl. Prof. H. Soedarto, Tembalang, Kota Semarang, 50275, Jawa Tengah, Indonesia \\ ${ }^{2} J u r u s a n$ Perencanaan Wilayah dan Kota, Universitas Diponegoro \\ Jl. Prof. H. Soedarto, Tembalang, Kota Semarang, 50275, Jawa Tengah, Indonesia \\ e-mail: iskandar_sillia@yahoo.com
}

Diterima: 20 April 2020, Direvisi: 11 Juni 2020, Disetujui: 03 Juli 2020

\begin{abstract}
Abstrak
Perkembangan pemanfaatan lahan terbangun yang semakin pesat dapat menimbulkan dampak bagi tata ruang, terutama dengan adanya alih fungsi lahan. Kondisi ini juga terjadi pada kawasan sekitar bandar udara Ahmad Yani Semarang, mengingat dengan adanya pengembangan bandar udara tersebut menyebabkan pergeseran pemanfaatan lahan pada kawasan sekitarnya. Penelitian ini bertujuan untuk melihat bagaimana keberadaan pengembangan bandar udara Ahmad Yani Semarang memberikan dampak terhadap pemanfaatan lahan di kawasan sekitar. Penelitian ini menggunakan metode deskriptif kuantitatif. Hasil penelitian menemukan bahwa perkembangan pemanfaatan lahan tidak terbangun menjadi lahan terbangun di wilayah penelitian semakin bertambah setiap tahunnya sebagaimana pada tahun 2016 luas lahan terbangun berjumlah $60.893 \mathrm{~m} 2$. adanya pengembangan bandar udara pada tahun 2017, luasan pemanfaatan lahan terbangun semakin bertambah seperti pada tahun 2017 s/d 2019 bertambah menjadi 247.917 m2. Meningkatnya perkembangan pemanfaatan lahan terbangun perlu adanya penetapan kebijakan pemanfaatan lahan secara khusus oleh Pemerintah Kota Semarang/Dinas Penataan Ruang untuk Kelurahan dengan tingkat nilai daya dukung 0,091 Ha/Jiwa. Sedangkan Kelurahan dibawah ambang batas tingkat daya dukung lahan 0,026 s/d 0,006 juga perlu pengawasan pemanfaatan lahan terbangun agar tidak melebihi ambang batas daya dukung lahan 0,100 Ha/Jiwa. Adapun kesesuaian lahan di wilayah penelitian hanya terdapat satu kategori kesesuaian lahan yaitu sesuai sebagai fungsi budidaya, dengan jumlah keseluruhan $1.691 \mathrm{Ha}$.
\end{abstract}

Kata kunci: pemanfaatan lahan, daya dukung lahan, kesesuaian lahan, bandar udara

\begin{abstract}
The development of the land use built that growing rapidly could makes an impact on spatial planning, especially to the land conversion. This condition also happened to the area around the Ahmad Yani airport in Semarang city, in case that the airport development caused a land use change in the surrounding area. This study aims to see how the presence of the development of Ahmad Yani Airport in Semarang has an impact on land use in the surrounding area. This study uses quantitative descriptive methods. The results of the study found that there was increase of land use development from not built to built up land in the study area for every year, as in 2016 the area of built up land amount of 60,893 m2. With the development of airports in 2017, the area of land use developed has increased as in 2017 to 2019, it has increased to 247,917 m2. Increasing the development of built land use requires the establishment of specific land use policies by the Semarang City Government / Spatial Planning Office for urban village with a carrying capacity value of
\end{abstract}


0.091 Hectare / Soul. While the urban village below the carrying capacity level of land 0.026 to 0.006 also needs supervision land use so that it does not exceed the threshold of carrying capacity land of 0.100 Hectare / Soul. As for land suitability the study area there is only one land suitability that is suitable as a funcation of culvitation, with a number whole of 1,691 Hectare.

Key words: land use, land carrying capacity, land suitability, airport

\section{PENDAHULUAN}

Keberadaan Bandar Udara umumnya akan diikuti oleh perubahan pemanfaatan lahan di kawasan sekitar Bandar Udara tersebut akibat pembangunan infrastruktur, seperti di bangunnya pusat perbelanjaan, perkantoran dan pembangunan lainnya yang memiliki hubungan erat dengan aktivitas ekonomi. Adanya Bandara Udara bisa berdampak positif maupun dampak negatif.

Menurut Xiong \& Beckhmann (2018) dampak positif dari keberadaan Bandar Udara adalah dapat mendorong investor untuk mengembangkan berbagai kegiatan ekonomi di kawasan sekitar Bandar Udara. Sedangkan dampak negatifnya adalah apabila pemanfaatan lahan untuk pembangunan di kawasan sekitar Bandar Udara tidak selaras dengan peruntukan pemanfaatan lahan yang ditetapkan dalam Rencana Tata Ruang, maka terjadi pelanggaran ketentuan pemanfaatan lahan. Hal ini juga sesuai dengan amanat UndangUndang Nomor 26 Tahun 2007 yang menyebutkan bahwa dalam peruntukan pemanfaatan ruang harus didasarkan pada kesesuaian peruntukannya sehingga dapat mengurangi dampak negatif akibat kesalahan dalam pemanfaatan ruang.

Bandar Udara Ahmad Yani merupakan Bandar Udara yang terletak di Kelurahan Tambakharjo, Kecamatan Semarang Barat, Kota Semarang. Pada awalnya Bandar Udara Ahmad Yani merupakan pangkalan udara TNI-AD, kemudian menjadi salah satu Badar Udara di Bawah PT Angkasa Pura pada tahun 1995, pada tahun 2004 terjadi penambahan fungsi menjadi Bandar Udara Internasional. Untuk meningkatkan fungsi tersebut maka pada tahun 2017 Bandar Udara Ahmad Yani dibangun satu terminal baru guna untuk meningkatkan kapasitas daya tampung penumpang yang lebih banyak serta luasan yang lebih besar dibandingkan Bandar Udara lama (Wibowo, 2016).

Pengembangan Bandar Udara Ahmad Yani dalam Rencana Tata Ruang Wilayah Kota Semarang tahun 2011-2031 ditetapkan sebagai BWK III yang direncanakan untuk pendistribusian fasilitas pelayanan regional meliputi perkantoran, perdagangan dan jasa. Berdasarkan data proyeksi penduduk RTRW Kota Semarang, menunjukan bahwa Kecamatan Semarang Barat akan mengalami peningkatan penduduk yang berdampak pada perkembangan kebutuhan ruang yang cukup pesat. Pertambahan penduduk yang semakin meningkat pada masa yang akan datang sehingga pemanfaatan ruang yang ada diperkirakan akan mengalami perubahan.

Pengembangan Bandar Udara Ahmad Yani termasuk salah satu faktor yang menyebabkan terjadinya perubahan pemanfaatan lahan di Kecamatan Semarang Barat, khususnya pada kawasan sekitar Bandar Udara yang menjadi lokasi penelitian. Dampak dilakukannya pengembangan Bandar Udara Ahmad Yani Semarang memberikan pengaruh terhadap perubahan pemanfaatan lahan di kawasan sekitar Bandar Udara dimana lahan tidak terbangun mulai berubah menjadi lahan terbangun yang berdampak terhadap perubahan fisik kawasan. Berdasarkan hasil pengamatan, adanya pengembangan Bandar Udara Ahmad Yani Semarang mulai diikuti oleh pembangunan perumahan, pusat perbelanjaan seperti pembangunan mall baru, toko, perkantoran dan juga 
pembangunan hotel bertaraf internasional di kawasan sekitar Bandar Udara. Hal tersebut membuktikan bahwa Bandar Udara tidak hanya dibangun sebagai infrastruktur transportasi yang berfungsi sebagai tempat pendaratan maupun pemberangkatan pesawat semata akan tetapi sangat erat kaitannya dengan aktivitas ekonomi, baik didalam maupun diluar kawasan bandara (Kurtiningsih, 2017).

Meningkatnya aktivitas ekonomi yang disebabkan oleh adanya Bandar Udara akan berdampak terjadinya perubahan pemanfaatan lahan terutama pemanfaatan lahan sebagai perumahan, komersial, industri dan lainnya di kawasan sekitar Bandar Udara (Suksmith \& Nitivattananon, 2015). Terjadinya alih fungsi lahan di kawasan sekitar Bandar Udara dikarenakan meningkatnya investasi dibidang non pertanian (Sepriana et al., 2014). Untuk itu, perencanaan yang tepat dalam pemanfaatan lahan pada kawasan sekitar Bandar Udara merupakan hal penting, mengingat dalam pengembangan Bandar Udara juga akan berkaitan dengan kondisi operasionalnya, sehingga terdapat kemungkinan dimana pada kawasan di sekitar bandar udara tidak cocok untuk dengan pemanfaatan lahan tertentu (Arantes et al, 2020).

Kesesuaian lahan dan daya dukung lahan merupakan salah aspek penting dalam pemanfaatan lahan yang harus diperhatikan dalam pembangunan. Menurut Lestari \& Arsyad (2018) kesesuaian lahan dalam pemanfaatan ruang merupakan indikator penentu dalam pengelolaan lingkungan yang tidak bisa terlepas dari aktivitas manusia dalam menetapkan pemanfaatan lahan untuk lokasi pembangunan fasilitas perkotaan.

Pesatnya pembangunan fisik di kawasan perkotaan akan diikuti dengan bertambahnya permintaan akan lahan untuk pembangunan (Bunawan \& Yuliastuti, 2017). Semakin meningkat aktivitas manusia, diikuti dengan jumlah penduduk

\section{METODE PENELITIAN}

Ruang lingkup penelitian ini adalah wilayah Kecamatan Semarang Barat, akan yang semakin bertambah namun ketersediaan sumber daya lahan yang terbatas dalam pemanfaatan untuk pembangunan maka diperlukan adanya upaya keseimbangan antara lingkungan dan pembangunan (Yuliastuti \& Fatchurochman, 2012).

Kesesuaian lahan dan daya dukung lahan merupakan faktor pertimbangan penting dalam pemanfaatan ruang wilayah secara berkelanjutan (Sadesmesmesli et al., 2017). Hana \& Labajos (2018) menambahkan bahwa perubahan atau pergeseran pemanfaatan lahan selain dipengaruhi oleh kesesuaian lahan dan daya dukungnya, juga dapat dipengaruhi oleh adanya konflik kepentingan serta kewenangan stakeholder.

Perkembangan pembangunan yang semakin pesat dapat menimbulkan dampak negatif bagi Tata Ruang terutama terjadinya alih fungsi lahan yang tidak sesuai dengan peruntukan akibat perkembangan aktivitas tersebut. Untuk menghindari dampak negative perkembangan pembangunan di kawasan sekitar Bandara Udara akibat adanya pengembangan Bandara Udara Ahmad Yani, maka dalam pemanfaatan lahan untuk pembangunan perlu mengutamakan kesesuaian lahan dan tingkat daya dukung lahannya.

Didalam penelitian ini bertujuan untuk (1) mengidentifikasi perkembangan pemanfaatan lahan di kawasan sekitar pengembangan Bandar Udara Ahmad Yani Semarang tahun 2016-2019, (2) menganalisis tingkat daya dukung lahan di kawasan sekitar pengembangan Bandar Udara Ahmad Yani Semarang, (3) menganalisis kesesuaian lahan di kawasan sekitar pengembangan Bandar Udara Ahmad Yani Semarang. Hasil dari penelitian diharapkan dapat menjadi kontribusi masukan informasi bagi stakeholder dalam meninjau kembali kesesuaian pemanfaatan lahan terhadap kawasan di sekitar Bandar Udara Ahmad Yani.

tetapi yang difokuskan hanya pada kawasan sekitar Bandar Udara yakni bagian utara Jl. Siliwangi dan Jl. Jenderal Sudirman yang 
meliputi Kelurahan Tawangsari, Tambakharjo, Gisik Drono, Krobokan, Karang Ayu, Kalibanteng Kulon, Krapyak, dan Tawang Mas. Adapun delapan
Kelurahan yang dipilih menjadi wilayah penelitian dapat dilihat pada peta administrasi wilayah Gambar 1.

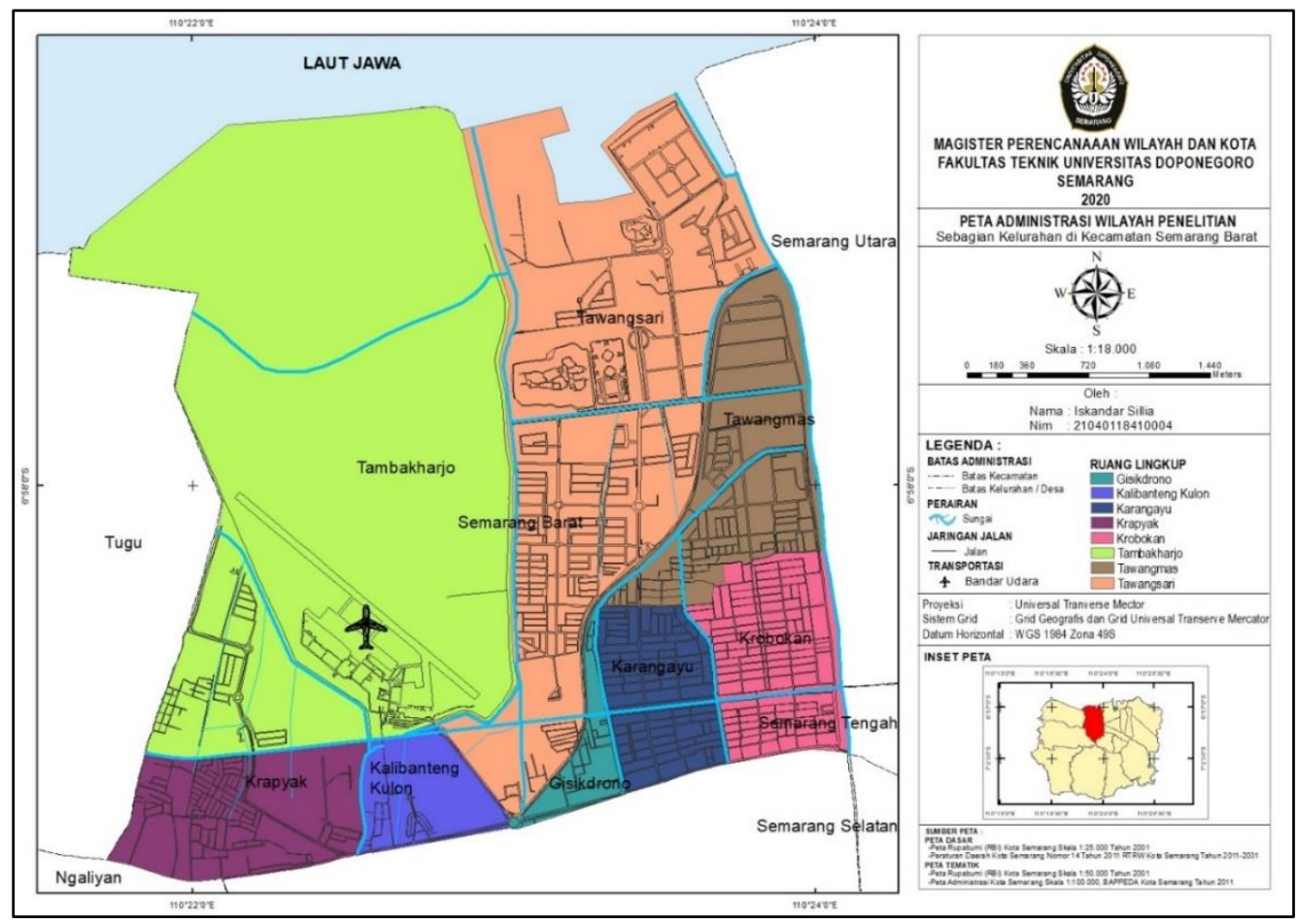

Gambar 1. Peta Administrasi Lokasi Penelitian

Adapun metode penelitian yang digunakan adalah deskriptif kuantitatif. Metode kuantitatif dapat diartikan sebagai metode yang dilakukan dengan cara perhitungan dengan tujuan mengkaji hipotesis yang telah ditetapkan (Sugiyono, 2017). Adapun teknik pengumpulan data yang dilakukan dalam penelitian dengan dua acara, yakni melalui survei primer dan survei sekunder untuk memperkuat analisis penelitian. Survei primer dilakukan dengan cara observasi lapangan. Sedangkan survey sekunder merupakan data yang diperoleh dari telaah dokumen.

Penelitian ini dilakukan sesuai dengan tujuan yang ingin dicapai dengan menggunakan variabel yang telah ditentukan. Berdasarkan hal tersebut maka tahap awal dari penelitian ini dilakukan adalah : 1). Mengidentifikasi perkembangan pemanfaatan lahan di kawasan sekitar Bandar Udara Ahmad Yani Semarang tahun 2016-2019 dengan menggunakan data landsat sentinel yang bersumber dari USGS
Explorer agar dapat menampilkan secara visual perkembangan pemanfaatan lahan mengingat dalam pemanfaaatan sumberdaya lahan biasanya tidak secara langsung tampak dari data citra sehingga perlu ditunjang dengan data IMB agar dapat mengetahui tingkat perkembangan pemanfaatan lahan terbangun dengan hasil yang akurat dari tahun 2016 s/d 2019.

2). Menganalisis tingkat daya dukung lahan di kawasan sekitar Bandar Udara dilakukan perhitungan berdasarkan standar Yeates (1980 dalam Muta'ali, 2012) untuk mengetahui jumlah penduduk eksisting serta luas lahan (Ha/Jiwa), sehingga dapat mengetahui ambang batas konsumsi lahan di kawasan sekitar pengembangan Bandar Udara Ahmad Yani Semarang dalam mendukung proses pengembangan pembangunan. Jumlah penduduk yang dapat didukung oleh sumber daya lahan pada lingkungan tertentu secara tepat dapat menghindari pemanfaatan lahan yang malampaui daya 


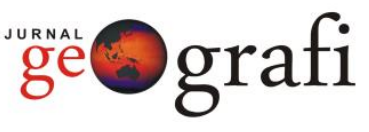

dukung lahan (Lisnawati \& Wibowo, 2009). Ilustrasi perhitungan konsumsi lahan yang dibutuhkan dalam menganalisis daya dukung lahan dapat dilihat pada Tabel 1.

\begin{tabular}{ccc}
\multicolumn{3}{c}{ Tabel 1. Konsumsi Lahan (Ha/Jiwa) } \\
\hline No $\begin{array}{l}\text { Jumlah } \\
\text { (Jiwa) }\end{array}$ & Penduduk & $\begin{array}{c}\text { Konsumsi } \\
\text { Lahan } \\
\text { (Ha/Jiwa) }\end{array}$ \\
\hline 1 & 10.000 & 0,100 \\
2 & 25.000 & 0,091 \\
3 & 50.000 & 0,086 \\
4 & 100.000 & 0,076 \\
5 & 250.000 & 0,070 \\
6 & 500.000 & 0,066 \\
7 & 1.000 .000 & 0,061 \\
8 & 2.000 .000 & 0,057 \\
\hline
\end{tabular}

Sumber: Yeates, 1980 (dalam Muta'ali, 2012)

3). Menganalisis kesesuaian lahan di kawasan sekitar Bandar Udara Ahmad Yani Semarang dilakukan dengan pengharkatan parameter kesesuaian pemanfaatan lahan yang sudah ditentukan nilai skoring yang mengacu pada Permen PU No 41 Tahun 2007 tentang pedoman kriteria teknis kawasan budidaya. Parameter yang digunakan diantaranya jenis tanah, kelerengan, dan intensitas curah hujan serta mempertimbangkan kawasan perlindungan setempat yang mengacu pada ketentuan PP No 26 Tahun 2008 tentang RTRW Nasional sehingga dapat diketahui lahan yang sesuai untuk dimanfaatkan sebagai lahan terbangun. Sebagaimana nilai klasifikasi parameter kesesuaian lahan dari dapat dilihat pada Tabel $2 \mathrm{~s} / \mathrm{d}$ Tabel 6.

Tabel 2. Klasifikasi Dan Nilai Skor Jenis

\begin{tabular}{|c|c|c|c|}
\hline \multicolumn{4}{|c|}{ Tanah } \\
\hline Kelas & Jenis Tanah & Kategori & $\begin{array}{l}\text { Nilai } \\
\text { Skor }\end{array}$ \\
\hline I & $\begin{array}{l}\text { Aluvial, Glei, } \\
\text { Planosol, } \\
\text { Hidromerf, } \\
\text { Laterik air } \\
\text { tanah }\end{array}$ & $\begin{array}{l}\text { Rendah/Ti } \\
\text { dak Peka } \\
\text { terhadap } \\
\text { erosi }\end{array}$ & 15 \\
\hline II & Latosol & $\begin{array}{l}\text { Sedang/Ag } \\
\text { ak Peka } \\
\text { terhadap } \\
\text { erosi }\end{array}$ & 30 \\
\hline
\end{tabular}

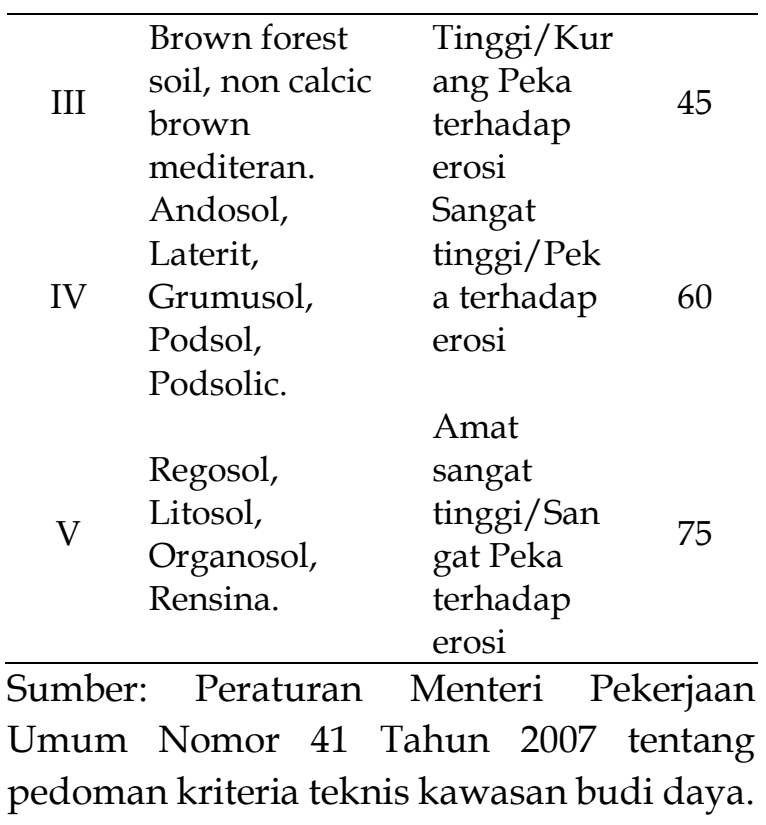

Penetapan nilai skor pada parameter jenis tanah didasarkan pada tekstur jenis tanah. Berdasarkan analisis peta digital RTRW Kota Semarang dengan mengacu pada Peraturan Menteri Pekerjaan Umum Nomor 41 Tahun 2007 tentang pedoman kriteria teknis kawasan budi daya, dapat diketahui kondisi jenis tanah di wilayah penelitian masuk dalam kategori rendah/tidak peka terhadap erosi dan di wilayah penelitian hanya terdapat satu kelas kriteria jenis tanah berdasarkan tingkat kepekaanya terhadap erosi yaitu jenis tanah Aluvial.

Tabel 3. Klasifikasi Dan Nilai Skor Kelerengan Lahan

\begin{tabular}{|c|c|c|c|}
\hline Kelas & Interval & Kelasifikasi & $\begin{array}{l}\text { Nilai } \\
\text { Skor }\end{array}$ \\
\hline I & $0-8 \%$ & Datar & 20 \\
\hline II & $8-15 \%$ & Landai & 40 \\
\hline III & $15-25 \%$ & $\begin{array}{l}\text { Agak } \\
\text { curam }\end{array}$ & 60 \\
\hline IV & $25-45 \%$ & Curam & 80 \\
\hline $\mathrm{V}$ & $>45$ & $\begin{array}{l}\text { Sangat } \\
\text { Curam }\end{array}$ & 100 \\
\hline
\end{tabular}

Sumber: Peraturan Menteri Pekerjaan Umum Nomor 41 Tahun 2007 tentang pedoman kriteria teknis kawasan budi daya. 
Adapun kondisi kemiringan lahan di wilayah penelitian berdasarkan hasil analisis peta digital RTRW Kota Semarang dan juga mengacu pada Peraturan Menteri Pekerjaan Umum Nomor 41 Tahun 2007 diketahui kondisi kelerengan lahan di wilayah penelitian hanya terdapat satu kelas kriteria kelerengan yakni $0-8 \%$ dengan kategori datar.

Tabel 4. Klasifikasi dan Nilai Skor Intensitas

\begin{tabular}{cclc}
\multicolumn{4}{c}{ Hujan } \\
\hline Kelas & $\begin{array}{c}\text { Intensitas } \\
\text { Hujan } \\
(\mathrm{mm} / \text { hari })\end{array}$ & Kategori & $\begin{array}{c}\text { Nilai } \\
\text { Skor }\end{array}$ \\
\hline I & $0-13,6$ & $\begin{array}{l}\text { Sangat } \\
\text { Rendah }\end{array}$ & 10 \\
II & $13,6-20,7$ & Rendah & 20 \\
III & $20,7-27,7$ & Sedang & 30 \\
IV & $27,7-34,8$ & Tinggi & 40 \\
V & $>34,8$ & Sangat & 50 \\
& & Tinggi & \\
\hline
\end{tabular}

Sumber: Peraturan Menteri Pekerjaan Umum Nomor 41 Tahun 2007 tentang pedoman kriteria teknis kawasan budi daya.

Adapun intensitas curah hujan di wilayah penelitian sama seperti intensitas curah hujan di Kota Semarang pada umumnya. Berdasarkan hasil analisis peta digital RTRW Kota Semarang dan juga mengacu pada Peraturan Menteri Pekerjaan Umum Nomor 41 Tahun 2007 diketahui Intensitas curah hujan di wilayah penelitian termasuk kategori tinggi yakni dengan intensitas curah hujan antara 27,7 - 34,8 $\mathrm{mm} /$ tahun yang menyebar disemua wilayah.

Setelah dilakukan skoring terhadap ketiga kriteria tersebut, maka selanjutnya dilakukan overlay dan penambahan pada masing-masing skor untuk memperoleh kriteria lahan kawasan yang sesuai (budidaya) maupun yang tidak sesuai (lindung). Perhitungan dalam penentuan kelasifikasi lahan potensial untuk penggunaan lahan terbangun adalah dengan hasil skoring dari kesesuaian lahan. Dalam tahap klasifikasi data kesesuaian lahan dilakukan teknik pengharkatan (penjumlahan dan pengurangan) jumlah dari harkat terendah di tambah dengan harkat tertinggi dan di bagi dengan jumlah kelas menurut rumus Hadi (1982 dalam Ananda, 2020). Untuk mendapatkan pengharkatan hasil kelas kesesuaian lahan dapat dilihat pada Tabel 5 berikut.

Tabel 5. Pengharkatan Parameter Kesesuaian Lahan

\begin{tabular}{lcc}
\hline Parameter & $\begin{array}{c}\text { Jumlah } \\
\text { Harkat } \\
\text { Terendah }\end{array}$ & $\begin{array}{c}\text { Jumlah } \\
\text { Harkat } \\
\text { Tertinggi }\end{array}$ \\
\hline Jenis Tanah & 15 & 75 \\
Kelerengan & 20 & 100 \\
Intensitas & 10 & 50 \\
Hujan & 45 & 225 \\
\hline \multicolumn{1}{c}{ Jumlah } &
\end{tabular}

Sumber: Hasil Perhitungan

$$
\begin{aligned}
\text { Range } & =45+225 \\
& =270: 3 \\
& =90
\end{aligned}
$$

Adapun kriteria kesesuaian pemanfaatan lahan berdasarkan dari hasil pengharkatan yang diperkenankan pada setiap pemanfaatan lahan dapat dilihat pada Tabel 6. berikut.

Tabel 6. Kriteria Penetapan Kesesuaian Pemanfaatan Lahan

\begin{tabular}{clc}
\hline No & \multicolumn{1}{c}{ Fungsi Lahan } & Skor \\
\hline \multirow{2}{*}{1} & Sesuai Sebagai Fungsi & $<90$ \\
& Kawasan Budidaya & $>90-$ \\
2 & Sesuai Sebagai Fungsi & 180 \\
& Kawasan Penyangga & $>180-$ \\
\multirow{2}{*}{3} & Sesuai Sebagai Fungsi & 270 \\
\cline { 2 - 3 } & Kawasan Lindung &
\end{tabular}

Sumber: Hasil perhitumgan dari parameter

Selanjutnya dari data hasil analisis fungsi pemanfaatan lahan kawasan tersebut di overlay kawasan perlindungan setempat sehingga dapat diketahui lahan sesuai untuk digunakan sebagai lahan terbangun di kawasan sekitaran pengembangan Bandara Ahmad Yani Semarang. Adapun terkait kawasan perlindungan setempat, sebagaimana mengacu pada ketentuan Peraturan Pemerintah Nomor 26 Tahun 2008 Tentang Rencana Tata Ruang Wilayah Nasional sebagaimana terdapat pada Tabel 7 berikut. 
Tabel 7. Kriteria Penetapan Kawasan Lindung Setempat

\begin{tabular}{ccc}
\hline No & $\begin{array}{c}\text { Jenis Kawasan Lindung } \\
\text { Setempat }\end{array}$ & Sempadan \\
\hline 1 & Mata Air & $200 \mathrm{~m}$ \\
2 & Sungai Besar & $100 \mathrm{~m}$ \\
3 & Sungai Kecil & $50 \mathrm{~m}$ \\
& Waduk/Danau & $100 \mathrm{~m}$ \\
\hline
\end{tabular}

Sumber: Peraturan Pemerintah Nomor 26 Tahun 2008 Tentang Rencana Tata Ruang Wilayah Nasional

Analisis kesesuaian lahan di kawasan sekitaran pengembangan Bandar Udara Ahmad Yani Semarang ini menggunakan analisis kuantitatif dengan penjumlahan nilai skoring yang telah ditentukan, dan kemudian hasilnya di overlay dengan kawasan perlindungan setempat dengan pendekatan Sistem Informasi Geografis (SIG). Output yang di hasilkan dari analisis ini adalah dapat mengetahui kesesuaian pemanfaatan lahan di kawasan sekitaran pengembangan Bandara Ahmad Yani Semarang. Adapun hasil akhir yang dihasilkan dari setiap tujuan penelitian ini adalah dapat mengetahui pemanfataan lahan eksisting dalam pemanfatan lahan terbangun di kawasan sekitar pengembangan Bandar Udara Ahmad Yani Semarang. Kerangka analisis penelitian dapat dilihat pada Gambar 2 dan untuk Tabel 8.

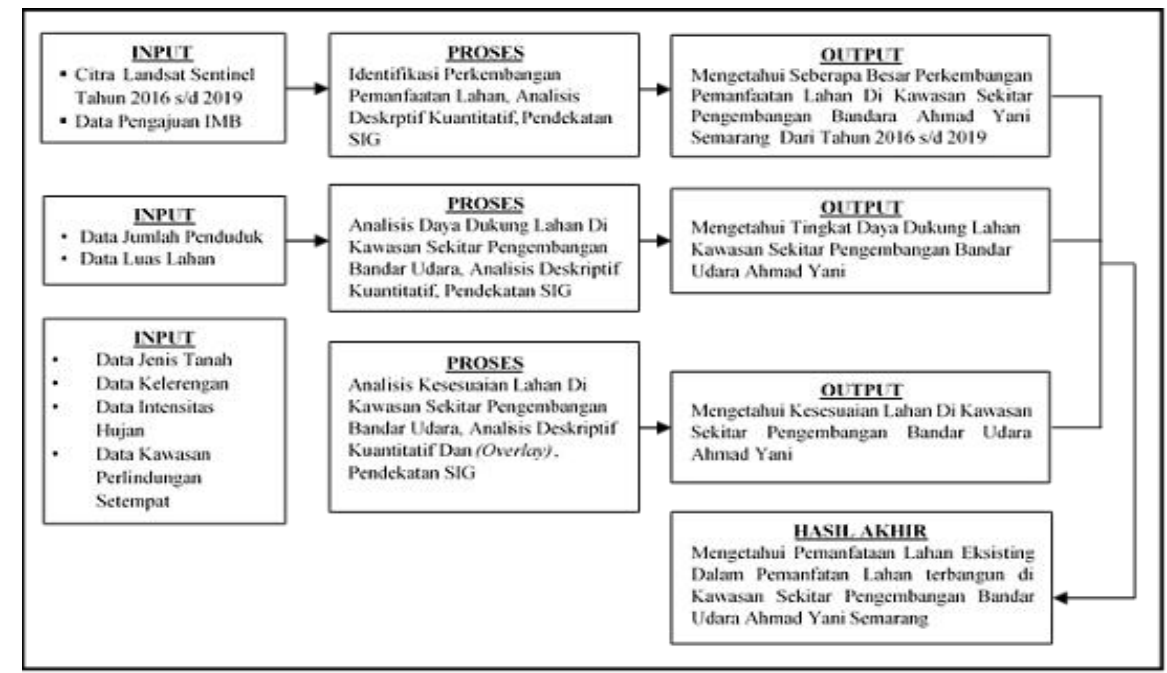

Gambar 2. Kerangka analisis penelitian

Tabel 8. Kebutuhan Data Penelitian

\begin{tabular}{|c|c|c|c|}
\hline No & Bahan/ Data & Bentuk Data & Sumber Data \\
\hline 1 & Citra Foto Udara & $\begin{array}{l}\text { Citra Landsat Sentinel } \\
\text { Tahun } 2016 \text { s/d } 2019\end{array}$ & USGS Explorer \\
\hline 2 & Data Pengajuan IMB & $\begin{array}{l}\text { Tabel Pengajuan IMB } \\
\text { Kecamatan Semarang } \\
\text { Barat }\end{array}$ & $\begin{array}{l}\text { Dinas Penanaman Modal- } \\
\text { PTSP Kota Semarang }\end{array}$ \\
\hline 3 & Data Jumlah Penduduk & Monografi Kelurahan & $\begin{array}{l}\text { Kantor Kelurahan di } \\
\text { Wilayah Penelitian }\end{array}$ \\
\hline 4 & Data Luas Lahan & Monografi Kelurahan & $\begin{array}{l}\text { Kantor Kelurahan di } \\
\text { Wilayah Penelitian }\end{array}$ \\
\hline 5 & Data Jenis Tanah & Shapefile (.Shp) & Bappeda Kota Semarang \\
\hline 6 & Data Kelerengan & Shapefile (.Shp) & Bappeda Kota Semarang \\
\hline 7 & Data Intensitas Hujan & Shapefile (.Shp) & Bappeda Kota Semarang \\
\hline 8 & $\begin{array}{l}\text { Data Kawasan } \\
\text { Perlindungan Setempat }\end{array}$ & Shapefile (.Shp) & Bappeda Kota Semarang \\
\hline
\end{tabular}

Sumber: Analisis Penyusun (2020) 
HASIL DAN PEMBAHASAN

Perkembangan Pemanfaatan Lahan Di Kawasan Sekitar Bandar Udara Ahmad Yani Semarang Tahun 2016-2019

Identifikasi tingkat perkembangan pemanfaatan lahan dalam penelitian ini menggunakan data berupa peta citra landsat sentinel yang bersumber dari USGS Explorer untuk menampilkan secara visual perkembangan pemanfaatan lahan dari tahun perekaman 2016 s/d 2019, di 8 (delapan) Kelurahan yang menjadi wilayah penelitian di Kecamatan Semarang Barat Untuk menghitung luasan perkembangan pemanfaatan lahan berdasarkan data pengajuan IMB.

Dalam perkembangan pemanfaatan lahan periode empat tahun dilihat dari citra landsat sentinel terjadi perubahan dalam pemanfaatan lahan sebagaimana sebagian dari lahan tidak terbangun (lahan hijau) yang mulai berkurang dikarenakan alih fungsi menjadi lahan terbangun. Berdasarkan data pengajuan IMB perubahan lahan tidak terbangun menjadi lahan terbangun diperuntukan sebagai rumah tinggal, kantor, ruko, toko, dan lainnya.
Perkembangan pemanfaatan lahan dalam periode empat tahun dari $2016 \mathrm{~s} / \mathrm{d}$ tahun 2019 di wilayah penelitian, berdasarkan hasil identifikasi dapat diketahui Kelurahan dengan tingkat perkembangan pemanfaatan lahan terbangun dengan jumlah terbanyak adalah Kelurahan Tawang Mas di bandingkan dengan Kelurahan lainnya. Peningkatan perkembangan pemanfaatan lahan lebih dominan di Kelurahan Tawang Mas dikarenakan berada pada jalur utama menuju Bandar Udara Ahmad Yani sehingga perkembangan pembangunan sarana prasana juga lebih meningkat di Kelurahan tersebut.

Perkembangan pemanfaatan lahan di Kelurahan Tawang Mas sejak dimulainya pengembangan Bandar Udara pada tahun 2017, berdasarkan data pengajuan IMB tahun 2017 s/d 2019 terjadi peningkatan pemanfaatan lahan terbangun dengan jumlah $162.854 \mathrm{~m}^{2}$ Sehingga lahan non terbangun (lahan kosong) semakin berkurang. Adapun data perubahan luas pemanfaatan lahan yang diperoleh dari data pengajuan IMB dari tahun 2016 s/d tahun 2019 dapat dilihat pada Tabel 9 berikut.

Tabel 9. Perkembangan Pemanfaatan Lahan Terbangun Di Wilayah Penelitian Berdasarkan IMB Tahun 2016 s/d 2019

\begin{tabular}{|c|c|c|c|c|c|c|c|}
\hline \multirow[b]{2}{*}{ Kelurahan } & \multirow[b]{2}{*}{ Peruntukan } & \multicolumn{4}{|c|}{ Luas Lahan Mendirikan Bangunan (M²) } & \multirow{2}{*}{$\begin{array}{l}\text { Perubahan } \\
\text { Luas } \\
\text { Lahan } \\
\text { Terbangun } \\
\left(\mathrm{M}^{2}\right)\end{array}$} & \multirow[b]{2}{*}{$\begin{array}{c}\text { Persentase } \\
(\%)\end{array}$} \\
\hline & & 2016 & 2017 & 2018 & 2019 & & \\
\hline Gisikdrono & Bangunan & 4.527 & 3.895 & 1.526 & 9.673 & 15.094 & 6,09 \\
\hline $\begin{array}{l}\text { Kalibanteng } \\
\text { Kulon }\end{array}$ & Bangunan & 5.229 & 2.114 & 1.014 & 2.515 & 5.643 & 2,28 \\
\hline Krapyak & Bangunan & 1.986 & 4.921 & 18.792 & 211 & 23.924 & 9,66 \\
\hline $\begin{array}{l}\text { Tambakharj } \\
\text { o }\end{array}$ & Bangunan & 9.432 & 2.160 & 1.073 & 1.234 & 4.467 & 1,81 \\
\hline Tawangsari & Bangunan & 21.084 & 5.739 & 4.359 & 6.728 & 16.826 & 6,78 \\
\hline Karangayu & Bangunan & 3.553 & 4.721 & 3.897 & 3.082 & 11.700 & 4,72 \\
\hline Krobokan & Bangunan & 3.215 & 2.513 & 672 & 4.224 & 7.409 & 2,99 \\
\hline $\begin{array}{l}\text { Tawang } \\
\text { Mas }\end{array}$ & Bangunan & 11.867 & 9.787 & 150.664 & 2.403 & 162.854 & 65,67 \\
\hline Jumlah & & 60.893 & 35.850 & 181.997 & 30.070 & 247.917 & 100 \\
\hline
\end{tabular}

Sumber: DPM-PTSP Kota Semarang dan hasil penelitian, 2020 
Berdasarkan Tabel 9 dapat diketahui bahwa luasan lahan mendirikan bangun pada tahun 2016 sebelum pengembangan bandara Ahmad Yani sebesar $60.893 \mathrm{~m}^{2}$ dan setelah mulai adanya pengembangan bandara pada tahun 2017, perubahan luasan terbangun semakin bertambah. Dari kurun waktu tiga tahun yaitu dari 2017 s/d 2019 perkembangan pemanfaatan lahan untuk pembangunan meningkat dengan total perubahan luas lahan terbangun $247.917 \mathrm{~m}^{2}$.

Perubahan pemanfaatan lahan dari tidak terbangun menjadi lahan terbangun secara umum terjadi di semua Kelurahan di wilayah penelitian, perkembangan tersebut ditandai dengan munculnya beberapa pembangunan rumah tinggal, toko/ruko, hotel, kantor, dan juga pembangunan pusat perbelanjaan mall, dan pembangunan lainnya.

Adanya peningkatan pemanfaatan lahan terbangun dari tahun 2017 s/d 2019 sehingga mengindikasikan bahwa kawasan sekitar pengembangan Bandar Udara Ahmad Yani Semarang mengalami perkembangan pemanfaatan lahan sebagaimana setiap tahun secara keseluruhan mulai berkurangnya lahan non terbangun (lahan hijau) dapat dilihat juga pada Gambar 3 berikut.

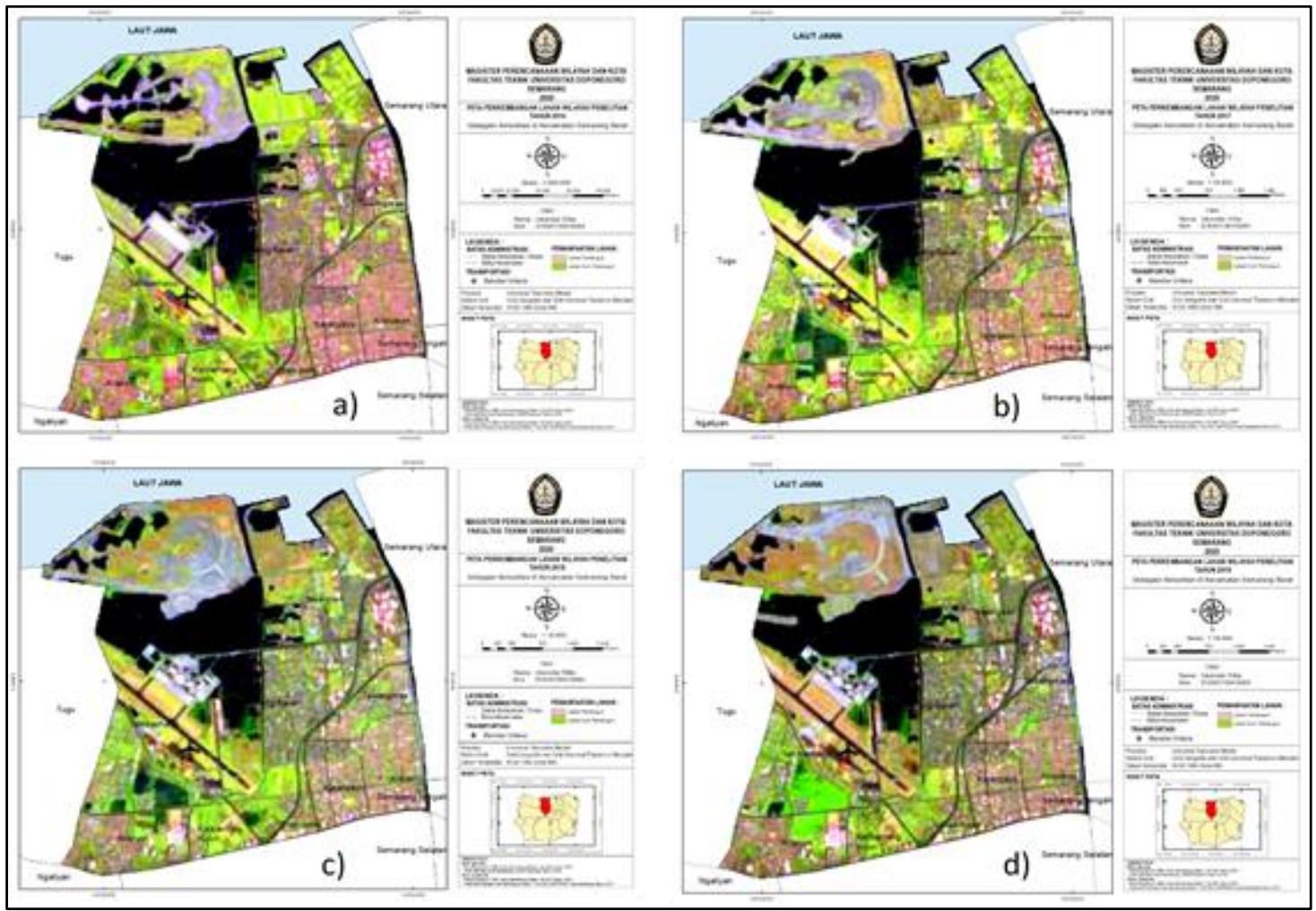

Gambar 3. Peta perkembangan pemanfaatan lahan di wilayah penelitian Kecamatan Semarang Barat tahun, a) 2016, b) 2017, c) 2018, d) 2019

(Sumber: Hasil penelitian, 2020)

Dari Gambar 3 di atas dapat diketahui dalam periode empat tahun yaitu 2016 s/d 2019 terjadi perkembangan pemanfaatan lahan dari lahan non terbangun menjadi lahan terbangun di kawasan sekitar pengembangan Bandar Udara Ahmad Yani secara menyeluruh yang menyebabkan mulai berukurangnya area hijau atau lahan kosong di sekitar kawasan pengembangan Bandar Udara khususnya di seluruh wilayah penelitian.

\section{Daya Dukung Lahan Di Kawasan Sekitar Bandar Udara Ahmad Yani Semarang. \\ Perkembangan berbagai kegiatan perkotaan yang ada di wilayah penelitian kawasan sekitar pengembangan Bandar Udara Ahmad Yani Semarang, berupa}


kegiatan permukiman, perdagangan dan jasa, perkantoran, kegiatan pendidikan dan kegiatan transportasi (Bandar Udara) sehingga menjadikan perkembangan lahan terbangun semakin bertambah, dengan adanya fenomena tersebut sehingga diperlukan analisis daya dukung guna memberikan informasi dalam menilai tingkat daya dukung lahan dalam mendukung segala aktivitas manusia yang berada di wilayah tersebut.

Konsep daya dukung lahan digunakan untuk memahami ambang batas kritis kemampuan yang dimiliki oleh suatu daerah dalam mendukung proses pengembangan pembangunan, dengan melihat perbandingan antara jumlah lahan yang dimiliki dan jumlah penduduk yang ada (Muta'ali, 2012). Adapun analisis daya dukung lahan berdasarkan daya tampung, dihitung dengan menggunakan variabel luasan lahan dibagi dengan jumlah penduduk eksisting, dengan rumus sebagai berikut:

$$
\begin{array}{ll}
\mathrm{A} & =\mathrm{L} / \mathrm{P} \\
\mathrm{A} & =\text { Daya Dukung Lahan } \\
\mathrm{L} & =\text { Luas Lahan (Ha) } \\
\mathrm{P} & =\text { Populasi Penduduk (Jiwa) }
\end{array}
$$

Apabila nilai daya dukung lahan (A) tersebut melebihi nilai konsumsi lahan yang ditentukan (standar Yeates) maka dikatakan populasi penduduk pada wilayah tersebut sudah melebihi daya dukungnya (diluar ambang batas), nilai daya dukung lahan ditunjukan dengan konsumsi lahan (Ha/Jiwa) untuk berbagai ukuran kota menurut Yeates (1980 dalam Muta'ali 2012).

Menurut standar konsumsi lahan yang ditentukan Yates, di kawasan sekitar Pengembangan Bandar Udara khususnya wilayah penelitian bila dirinci menurut Kelurahan hanya terdapat satu Kelurahan yang mendekati ambang batas konsumsi lahan yakni Kelurahan Kalibanteng Kulon dengan daya dukung sebesar 0,091 Ha/Jiwa sehingga dengan demikian pemanfaatan lahannya perlu pengawasan.

Sedangkan Kelurahan yang memiliki konsumsi lahan di bawah standar dan masih mampu menampung jumlah penduduk serta perkembangan pembangunan masih dimungkinkan adalah Kelurahan Gisikdrono, Kelurahan Krapyak, Kelurahan Tambak Harjo, Kelurahan Tawangsari, Kelurahan Karangayu, Kelurahan Krobokan, dan Kelurahan Tawang Mas.

Selain itu, perlu mempertimbangkan kebijakan arah pengembangan wilayah yang tertuang didalam Rencana Tata Ruang. tingkat daya dukung lahan di wilayah penelitian kawasan sekitar pengembangan Bandar Udara Ahmad Yani Semarang dapat dilihat pada Tabel 8 berikut.

Tabel 8. Tingkat Daya Dukung Lahan Di Wilayah Penelitian

\begin{tabular}{lccc}
\hline Kelurahan & $\begin{array}{c}\text { Luas } \\
\text { Lahan } \\
(\mathrm{Ha})\end{array}$ & $\begin{array}{c}\text { Jumlah } \\
\text { Pend } \\
\text { (Jiwa) }\end{array}$ & $\begin{array}{c}\text { Daya } \\
\text { Dukung } \\
\text { Lahan } \\
\text { (Ha/ } \\
\text { Jiwa) }\end{array}$ \\
\hline Gisikdrono & 396 & 18.835 & 0,021 \\
Kalibanteng & 709 & 7.789 & 0,091 \\
Kulon & & & \\
Krapyak & 114 & 7.454 & 0,015 \\
Tambakharjo & 87 & 3.270 & 0,026 \\
Tawangsari & 66 & 6.877 & 0,009 \\
Karangayu & 98 & 9.056 & 0,010 \\
Krobokan & 97 & 14.605 & 0,006 \\
Tawang Mas & 124 & 8.959 & 0,013 \\
\hline
\end{tabular}

Sumber: Hasil Penelitian, 2020

Dari Tabel 8 di atas dapat diketahui bahwa pertumbuhan dan perkembangan berbagai kegiatan perkotaan yang ada di wilayah penelitian berupa kegiatan permukiman, perdagangan dan jasa, perkantoran, pendidikan dan kegiatan transportasi (Bandar Udara) membawa pengaruh terhadap pemanfaatan lahan sehingga menjadikan pertumbuhan lahan terbangun semakin tinggi, dan hal tersebut memperlihatkan di Kecamatan Semarang Barat khususnya wilayah penelitian semakin diminati.

Beragamnya kegiatan perkotaan di wilayah penelitian dapat mempengaruhi tingkat daya dukung lahannya, sebagaimana diwilayah penelitian dengan semakin bertambahnya pemanfaatan lahan terbangun terdapat satu Kelurahan yang pemanfaatan lahan terbangunnya 
mendekati ambang batas daya dukung lahan seperti yang seperti yang terjadi di Kelurahan Kalibanteng Kulon dengan tingkat nilai daya daya dukung 0,091 Ha/Jiwa, sehingga perlu adanya penetapan kebijakan pemanfaatan lahan secara khusus oleh Pemerintah terkait di Kelurahan tersebut, dalam hal ini Pemerintah Kota Semarang/Dinas Penataan Ruang Kota Semarang, karena untuk fungsi perencanaan, pengawasan dan pengendalian sepenuhnya ada di dinas tersebut, sehingga dengan demikian diharapkan Kelurahan Kalibanteng Kulon yang memiliki tingkat nilai daya dukung lahan yang mendekati ambang batas pemanfaatan lahan terbangun, dengan adanya pengawasan dalam pemanfaatan lahan terbangun dapat mencegah bertambahnya pemanfaatan lahan terbangun yang dapat melebihi ambang batas daya dukung lahan.

Sedangkan Kelurahan yang masih jauh berada dibawah ambang batas tingkat daya dukung lahan dengan nilai daya dukung lahan 0,026 sampai dengan 0,006 Ha/Jiwa dalam pemanfaatan lahan terbangun juga perlu memperhatikan intensitas ruang, yang dilakukan dengan mempertimbangkan kondisi pemanfaatan lahan eksisting dengan melihat luasan lahan terbangun dan tidak terbangun diwilayah tersebut sehingga pemanfaatan lahan terbangun di wilayah tersebut tidak melebihi ambang batas daya dukung lahan 0,100 Ha/Jiwa yang ditentukan. Adapun peta daya dukung lahan wilayah penelitian dapat dilihat pada Gambar 4 berikut.

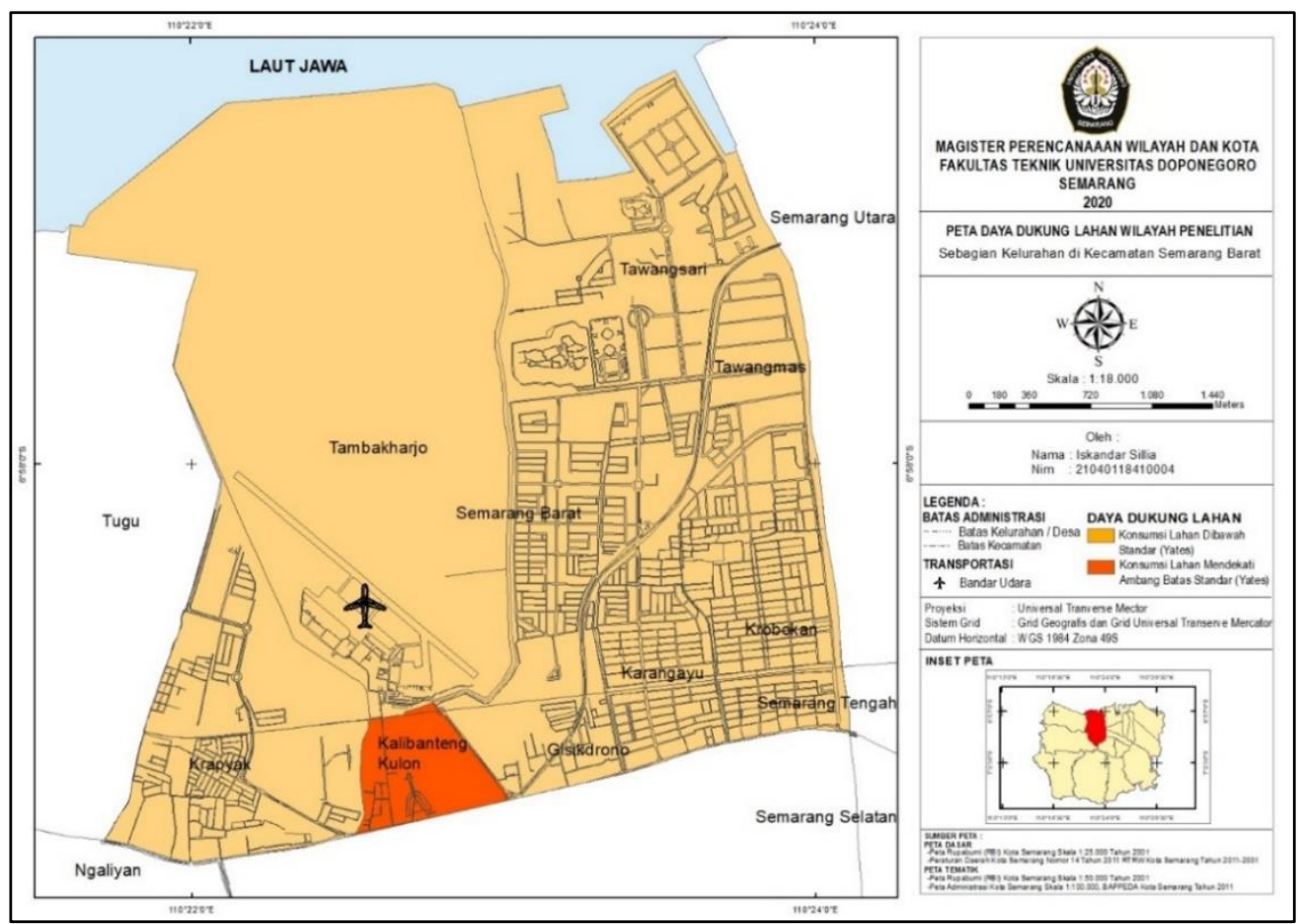

Gambar 4. Peta Tingkat Daya Dukung Lahan Di Wilayah Penelitian

(Sumber: Hasil Penelitian, 2020)

\section{Kesesuaian Lahan Di Kawasan Sekitar Bandar Udara Ahmad Yani Semarang}

Analisis ini dilakukan untuk melihat fungsi kawasan di 8 (delapan) Kelurahan yang menjadi wilayah penelitian yang potensial untuk dapat dimanfaatkan sebagai lahan terbangun dengan memperhatikan faktor-faktor yang dapat mempengaruhinya. Adapun hasil akhir penentuan kriteria kesesuaian lahan berdasarkan overlay beberapa parameter dengan penjumlahan nilai skoring yang sudah ditetapkan kemudian dikelompokkan menjadi tiga fungsi lahan berdasarkan nilai total 
penjumlahan skoring, yaitu apabila nilai total skroing $<90$ maka sesuai sesuai sebagai fungsi budidaya, sedangkan untuk sesuai bersyarat atau penyangga $>90-180$, dan tidak sesuai atau lindung apabila nilai total skoring $>180-270$.

Selain dengan menggunakan beberapa parameter yaitu jenis tanah, kemiringan lahan, dan intensitas curah hujan juga perlu dilengkapi dengan penetapan kawasan perlindungan setempat yang mengacu pada ketentuan Peraturan Pemerintah Nomor 26 Tahun 2008 tentang RTRWN, sehingga mendapatkan arahan pemanfaatan lahan kawasan yang sesuai dengan fungsinya.

Adapun hasil dari analisis kesesuaian lahan ini berupa peta kesesuaian lahan yang menginformasikan fungsi lahan pada wilayah penelitian yang dapat dimanfaatkan sesuai peruntukannya. Berdasarkan analisis peta digital dengan mengacu pada Peraturan Menteri Pekerjaan Umum Nomor 41 tahun 2007 tentang pedoman kriteria teknis kawasan budi daya, dapat diketahui kondisi jenis tanah di wilayah penelitian hanya terdapat jenis tanah alluvial dan tidak ditemui jenis tanah yang peka terhadap erosi seperti jenis tanah regosol, latosol, organosol, dan rezina.

Adapun jenis tanah alluvial masuk dalam kategori rendah/tidak peka terhadap erosi. dan di wilayah penelitian hanya terdapat satu kelas kriteria jenis tanah berdasarkan tingkat kepekaanya terhadap erosi.

Kondisi kemiringan lahan di wilayah penelitian berdasarkan hasil analisis dapat diketahui kondisi kelerengan lahan di wilayah penelitian tidak berada pada lereng yang landai, agak curam, curam, maupun sangat curam. Secara keseluruhan wilayah penelitian berada pada kemiringan lahan 0-8 $\%$ (datar) sehingga dalam pemanfaatan lahan untuk pembangunan relativ lebih mudah dibandingkan berada pada kemiringan lahan $>8 \%$. dan di wilayah penelitian hanya terdapat satu kelas kriteria kelerengan berdasarkan tingkat kepekaanya terhadap erosi.

Intensitas curah hujan di wilayah penelitian sama seperti intensitas curah hujan di Kota Semarang pada umumnya. Berdasarkan hasil analisis diketahui intensitas curah hujan di wilayah penelitian masuk dalam kategori tinggi yakni dengan intensitas curah hujan antara 27,7 - 34,8 $\mathrm{mm} /$ tahun yang menyebar disemua wilayah. Dengan intensitas curah hujan yang tinggi dapat mempengaruhi kesesuaian lahan untuk pemanfaatan pembangunan, dikarenakan erat kaitannya dengan kondisi jenis tanah dan erosi.

Hasil analisis menunjukkan bahwa lahan di wilayah penelitian khususnya kawasan sekitar pengembangan Bandar Udara Ahmad Yani Semarang hanya terdapat satu kategori fungsi lahan yakni sesuai sebagai fungsi budidaya. Adapun luas kesesuaian lahan berdasarkan hasil analisis tersebut dapat dilihat pada Tabel 9.

Tabel 9. Luas Kesesuaian Lahan Wilayah Penelitian Di Setiap Kelurahan

\begin{tabular}{lc}
\hline \multirow{2}{*}{ Kelurahan } & $\begin{array}{c}\text { Sesuai Untuk } \\
\text { Fungsi Budidaya }\end{array}$ \\
\cline { 2 - 2 } & Luas (Ha) \\
\hline Kelurahan Tawangsari & 396 \\
\hline $\begin{array}{l}\text { Kelurahan Tambak } \\
\text { Harjo }\end{array}$ & 709 \\
\hline Kelurahan Gisik Drono & 114 \\
\hline Kelurahan Krobokan & 87 \\
\hline Kelurahan Karang Ayu & 66 \\
\hline $\begin{array}{l}\text { Kelurahan Kalibanteng } \\
\text { Kulon }\end{array}$ & 98 \\
\hline Kelurahan Krapyak & 97 \\
\hline Kelurahan Tawang Mas & 124
\end{tabular}

Sumber: Hasil Penelitian, 2020 
Tabel 9 di atas menunjukan luasan kesesuaian lahan di wilayah penelitian berdasarkan hasil analisis dengan mempertimbangkan faktor kelerengan, jenis tanah, dan intensitas curah hujan yang telah di overlay serta dilakukan penjumlahan nilai skoring sehingga didapatkan jumlah total skoring 75 sebagaiman jika hasil penjumlah berada pada nilai skor $<90$ maka lahan tersebut masuk dalam kategori sesuai sebagai fungsi budidaya, sedangkan nilai skor >90-180 masuk kategori sesuai bersyarat atau sebagai fungsi penyangga, dan nilai skor >180-270 masuk sebagai kategori tidak sesuai atau sebagai fungsi lindung.
Dari hasil tersebut kemudian dilakukan overlay dengan penetapan kawasan perlindungan setempat yang mengacu pada ketentuan Peraturan Pemerintah Nomor 26 Tahun 2008 Tentang RTRW Nasional. Adapun peruntukan lahan yang sesuai sebagai fungsi budidaya terbesar terdapat di Kelurahan Tambak Harjo sebsar 709 Ha, sedangkan Kelurahan yang memiliki lahan sesuai sebagai fungsi budidaya terkecil adalah Kelurahan Karang Ayu sebesar $66 \mathrm{Ha}$. Adapun peta kesesuaian lahan di wilayah penelitian dapat dilihat pada Gambar 5 berikut.

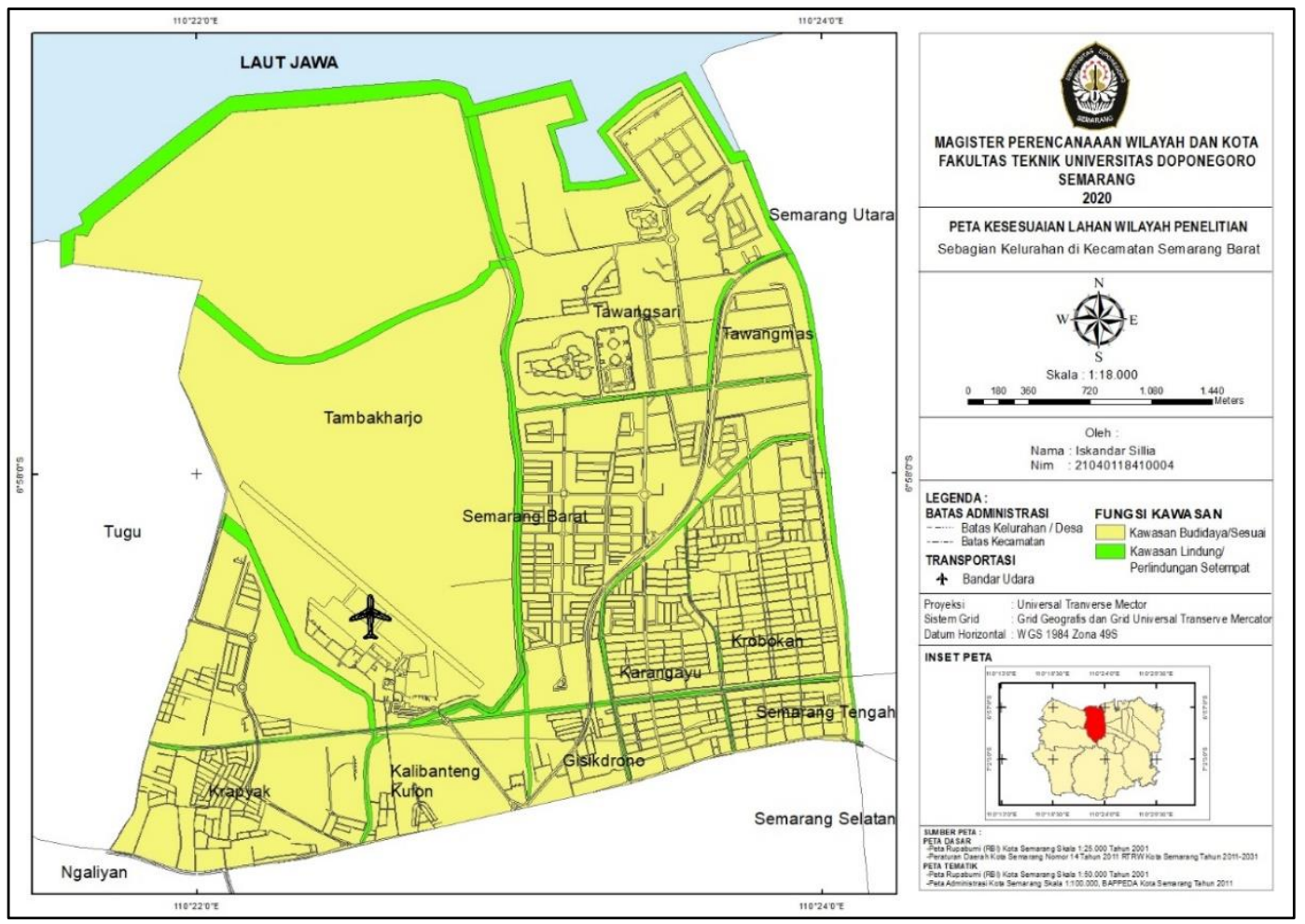

Gambar 5. Peta Kesesuaian Lahan Di Wilayah Penelitian

(Sumber : Hasil Penelitian, 2020

Berdasarkan Gambar 5 diketahui secara umum di wilayah penelitian kesesuaian lahannya sesuai sebagai fungsi budidaya, sehingga dalam pemanfaatan lahan untuk menampung berbagai fungsi kegiataan perkotaan seperti pembangunan permukiman, perkantoran, perdagangan dan jasa, industri, dan maupun pembangunan lainnya baik yang telah, sedang dan akan berkembang diwilayah penelitian sangat sesuai dengan karakteristik lahannya sebagaimana berdasarkan hasil overlay dan penjumlahan nilai skor secara umum terdapat satu kategori fungsi lahan yaitu sesuai sebagai fungsi budidaya.

Namun dalam pemanfaatan lahan untuk pengembangan pembangunan perlu 
memperhatikan kawasan perlindungan setempat dan peruntukan pemanfaatan lahan Rencana Tata Ruang sebagaimana di wilayah penelitian telah ditetapkan sebagai kawasan pengembangan pusat-pusat kegiatan perkotaan dan permukiman, disamping merupakan perlindungan dan revitalisasi kawasan-kawasan bersejarah maupun budaya, serta pusat-pusat permukiman padat. Sehingga diharapkan dengan memperhatikan peruntukan pemanfaatan lahan yang telah ditetapkan dalam Rencana Tata Ruang tersebut maka pemanfaatan lahan (eksisting) yang terjadi tetap berada pada pemanfaatan yang tepat sehingga dapat meminimalisir tingkat inkonsistensi antara pemanfaatan lahan eksisting dengan pemanfaatan lahan Rencana Tata Ruang.

\section{KESIMPULAN}

Perkembangan pemanfaatan lahan terbangun di kawasan sekitar Bandar Udara Ahmad Yani Semarang semakin bertambah setiap tahunnya, sebagaimana pada tahun 2016 total luas lahan terbangun sebesar $60.893 \mathrm{~m}^{2}$ dan setelah mulai adanya pengembangan bandara pada tahun 2017, luasan pemanfaatan lahan terbangun semakin bertambah seperti pada tahun 2017 s/d 2019 total luas lahan terbangun bertambah menjadi $247.917 \mathrm{~m}^{2}$. Perkembangan pemanfaatan lahan terbangun yang semakin meningkat perlu adanya penetapan kebijakan pemanfaatan lahan secara khusus oleh Pemerintah Kota Semarang/Dinas Penataan Ruang, untuk Kelurahan yang mendekati ambang batas daya dukung lahan seperti di Kelurahan Kalibanteng Kulon dengan tingkat nilai daya dukung 0,091 $\mathrm{Ha} /$ Jiwa sebagaimana untuk fungsi perencanaan, pengawasan dan pengendalian sepenuhnya ada di dinas tersebut. Sedangkan Kelurahan dibawah ambang batas tingkat daya dukung lahan 0,026 sampai dengan 0,006 Ha/Jiwa juga perlu adanya pengawasan secara berkala setiap tahunnya agar pemanfaatan lahan terbangun tidak melebihi ambang batas daya dukung lahan. Secara umum di wilayah penelitian terdapat satu kategori kesesuaian lahan yaitu sesuai sebagai fungsi budidaya untuk peruntukan pemanfaatan lahan terbangun. Peruntukan lahan yang sesuai sebagai fungsi budidaya terbesar terdapat di Kelurahan Tambak Harjo sebsar $709 \mathrm{Ha}$, sedangkan Kelurahan yang memiliki lahan sesuai sebagai fungsi budidaya terkecil adalah Kelurahan Karang Ayu sebesar $66 \mathrm{Ha}$.

\section{UCAPAN TERIMA KASIH}

Penulis mengucapkan terima kasih kepada Universitas Diponegoro yang telah memberikan kesempatan diterima sebagai mahasiswa untuk melanjutkan studi di Program Magister Perencanaan Wilayah dan Kota.

\section{DAFTAR PUSTAKA}

Ananda, C. F. (2020). Permukiman Di Kecamatan Polokarto Kabupaten Sukoharjo Tahun 2019. Publikasi Ilmiah, Program Studi Geografi, Universitas Muhammadiyah Surakarta. Cited in http:/ / eprints.ums.ac.id/80672/12/cez a_NASKAH PUBLIKASI.pdf [6 juni 2020].

Arantes, B., Santos, G. S., \& Gomes, R. D. A. (2020). Land Use Policy Land use policy in the vicinity of airports: Analysis and lessons learned from the Brazilian situation. Land Use Policy, 90(November 2019), 104314.

Buanawan, F. T., \& Yuliastuti, N. (2017). Penilaian Rekomendasi Teknis Sebagai Pengendali Tata Guna Lahan di Kecamatan Magetan. Jurnal Pembangunan Wilayah Dan Kota, 13(11), 189-201.

Hana, K., \& Labajos-Rodríguez, B. (2018). Impacts of land-use and management changes on cultural agroecosystem services and environmental con $\mathrm{fl}$ icts A global review. Global Eniveronmental Change,50(September 2017), 41-59.

Kustiningsih, W. (2017). Kelompok Rentan dalam Pembangunan Kawasan Kota Bandara di Kulon Progo: Studi Kasus New Yogyakarta International Aiport (NYIA). Jurnal Pemikiran Sosiologi, 4(1).

Lestari, Senifa, Citra, \& Arsyad, M. (2018). Studi Penggunaan Lahan Berbasis Data 
Citra Satelit. Sains Dan Pendidikan Fisika (JSPF), 14(1).

Lisnawati, Y., \& Wibowo, A. (2009). Analisis Daya Dukung Lahan Di Kawasan Puncak Kabupaten Bogor. Penelitian Hutan Dan Tanaman, 6(1), 45-54.

Muta'ali, Lutfhi. (2012). Daya Dukung Lingkungan Untuk Perencanaan Pengembangan Wilayah. Yogyakarta: Badan Penerbit Fakultas Geografi UGM.

Peraturan Daerah Kota Semarang. (2011). Rencana Tata Ruang Wilayah Kota Semarang Tahun 2011-2031. Peraturan Daerah Nomor: 14 Tahun 2011. Walikota Semarang. Semarang.

Permen PU (Republik Indonesia). (2007). Peraturan Menteri Pekerjaan Umum Nomor 41 Tahun 2007 Tentang Pedoman Kriteria Teknis Kawasan Budi Daya. Menteri Pekerjaan Umum. Jakarta.

PP (Republik Indonesia). (2008). Peraturan Pemerintah Nomor 26 Tahun 2008 Tentang Rencana Tata Ruang Wilayah Nasional. Lembaran Negara RI Tahun 2008, No. 48. Sekretariat Negara. Jakarta.

Rahayua, Y. E., Ahyudanaria, E., \& Pratomoadmojoc, N. A. (2016). Land use development and its impact on airport access road. International Conference, Intelligent Planning Towards Smart Cities, 227 (November 2015), 31-37. Surabaya, Indonesia.

RI (Republik Indonesia). (2007). UndangUndang Nomor 26 Tahun 2007 Tentang Penataan Ruang. Lembaran Negara RI No. 4725.
Sadesmesli, I., Baskoro, D. P. T., \& Pravitasari, A. E. (2017). Daya Dukung Lahan Dalam Perencanaan Tata Ruang Wilayah (Studi Kasus Kabupaten Blitar, Jawa Timur). TATA LOKA, 19(4).

Sepriana, J., Karim, A., \& Indira. (2014). Dampak pengembangan bandara sultan iskandar muda terahadap alih fungsi lahan sawah dan nilai lant rent. Manajemen Sumberdaya Lahan, 3(2), 442451.

Sugiyono. (2017). Metode Penelitian Kuantitatif, Kualitatif dan RED. Bandung: Alfabeta.

Suksmith, P. L., \& Nitivattananon, V. (2015). Aviation Impacts on Property Values and Management: The Case of Suvarnabhumi International Airport. IATSS Research, 39(1), 58-71.

Wibowo, Wahyu, L. (2016). Proyek pengembangan bandara ahmad yani semarang (ppsrg) paket - 1. Laporan Praktik Kerja Proyek, Program Studi Teknik Sipil, Universitas Katolik Soegijapranata.

Xiong, C., \& Beckmann, V. (2018). Effects of Infrastructure on Land Use and Land Cover Change ( LUCC ): The Case of Hangzhou International. Sustainability, 16(4), 1-18.

Yuliastuti, N., \& Fatchurochman, A. (2012). Lingkungan Permukiman ( Studi Kasus: Kawasan Pendidikan Kelurahan Tembalang ). Jurnal PRESIPITASI, 9(1), 10-16. 